\title{
Xymarginatin: a new acetogenin inhibitor of mitochondrial electron transport from Xylopia emarginata Mart., Annonaceae
}

\author{
Trina Colman-Saizarbitoria, ${ }^{* 1}$ Linda Montilla, ${ }^{2}$ Maria Rodriguez, ${ }^{2}$ Aníbal Castillo, ${ }^{2}$ \\ Masahisa Hasegawa ${ }^{2}$
}

\author{
${ }^{1}$ Laboratorio de Modelado Molecular y Laboratorio de Bioensayos y Productos Naturales, Facultad de Farmacia, \\ Universidad Central de Venezuela, Apartado de Correos 40109, Nueva Granada-Caracas, Venezuela \\ ${ }^{2}$ Facultad de Ciencias, Universidad Central deVenezuela, Apartado de Correos 40109, \\ Nueva Granada-Caracas, Venezuela
}

\begin{abstract}
RESUMO: "Xymarginatin: uma nova acetogenina inibidora do transporte mitocondrial eletrônico de Xylopia emarginata Mart., Annonaceae". Uma nova acetogenina de Anonaceae, xymarginatin (1), foi isolada dos caules de Xyliopia emarginata Mart. (Annonaceae) por fracionamento biodirecionado usando o teste de letalidade em Artemia salina. A substância 1 representa uma acetogenina linear C-35, sema neis tetrahidrofureano ou epóxidos, mas com um grupo cetônico em C-10 e com uma dupla ligação cis separada por duas unidades metilênicas. A estrutura de 1 foi elucidada por ${ }^{1} \mathrm{H}$ e ${ }^{13} \mathrm{C}-\mathrm{RNM}$, COSY, HMBC, HMQC e HRMS. A habilidade de inibir a cadeia respiratória mitocondrial de 1 foi testada em ensaios de produção de oxigênio mitocondrial em fígado de ratos, com IC50 de $1720 \mathrm{nM}$; rotenona, controle positivo, apresentou $\mathrm{IC}_{50}$ de 34,8 nM. A toxicidade da substância 1 contra Artemia salina Leach foi de $\mathrm{LC}_{50} 127 \mu \mathrm{g} /$ $\mathrm{mL}$.
\end{abstract}

Unitermos: Xylopia emarginata, Annonaceae, acetogenina, transporte eletrônico.

\begin{abstract}
A new Annonaceous acetogenin, xymarginatin (1), was isolated from the twigs of Xyliopia emarginata Mart. (Annonaceae) by bioactivity-directed fractionation using lethality to brine shrimp. The compound 1 represents a linear C-35 Annonaceous acetogenin, lacking either tetrahydrofuran (THF) or epoxide rings, bearing a keto group at C-10, and possessing two cisdouble bonds separated by two methylenes units. The structure of $\mathbf{1}$ was elucidated by ${ }^{1} \mathrm{H}$ and ${ }^{13} \mathrm{C}-\mathrm{NMR}, \mathrm{COSY}, \mathrm{HMBC}, \mathrm{HMQC}$ and HRMS. The ability to inhibit the mitochondrial respiratory chain of Xymarginatin (1) was tested in a rat liver mitochondrial oxygen uptake assay, with $\mathrm{IC}_{50}$ value of $1720 \mathrm{nM}$; Rotenone as a positive control gave $\mathrm{IC}_{50} 34.8 \mathrm{nM}$. The toxicity of compound 1 against Artemia salina Leach gave $\mathrm{LC}_{50}$ of $127 \mu \mathrm{g} / \mathrm{mL}$.
\end{abstract}

Keywords: Xylopia emarginata, Annocaceae, acetogenin, electron transport.

\section{INTRODUCTION}

Annonaceous acetogenins constitute a broad group of secondary metabolites with impressive biological activities and have been considered as important leads for new anticancer drugs due to the ability to inhibit the NADH:ubiquinone oxidoreductase of the respiratory chain (mitochondrial complex I), main gate of the energy production in the cell (Zeng et al., 1996; Tormo et al., 2001; Bermejo et al., 2005), and they also are powerful inhibitors of the plasma membrane NADH oxidase of tumor cells (Morré et al., 1995). Acetogenins are selectively cytotoxic against cancerous cells and also effective for drug-resistant cancer cells, while exhibiting only minimal toxicity to 'normal' non-cancerous cells (Oberlies et al., 1997).

Xylopia genus is commonly used by traditional healers to treat malaria and others infectious diseases (Mesquita et al., 2007; Saúde-Guimaräes \& Faria, 2007). From Xylopia emarginata Mart. (Annonaceae) terpenoids (Moreira et al., 2007), flavonoids, steroids and alkaloids (Moreira et al., 2003), have been isolated from the leaves and fruits. To our knowledge, this is the first time that acetogenins have been described in this species.

The ethanol extract of twigs of Xylopia emarginata (Annonaceae), collected in the state of Amazonas (Venezuela), using brine shrimp lethality (BST)-directed fractionation (Meyer et al., 1982), have yielded a new acetogenin, xymarginatin (1), without a tetrahydrofuran (THF) nor an epoxide rings bearing a keto group at $\mathrm{C}-10$ and possessing two cis-double bond. Others linear Annonaceous acetogenins have been isolated previously (Colman-Saizarbitoria et al., 1998; Fall et al., 2002; Chih- 
Chuang et al., 2005; Colman-Saizarbitoria et al., 2008). In this study, also, we investigated for the ability to inhibit oxygen uptake by isolated rat liver mitochondria of the acetogenin xymarginatin $\mathbf{1}$.
$5 \mathrm{mM}$ glutamate, $1 \mathrm{mM}$ malate, and $20 \mathrm{mM}$ Tris- $\mathrm{HCl}$ at a $\mathrm{pH}$ of 7.4 and was stored at room temperature.

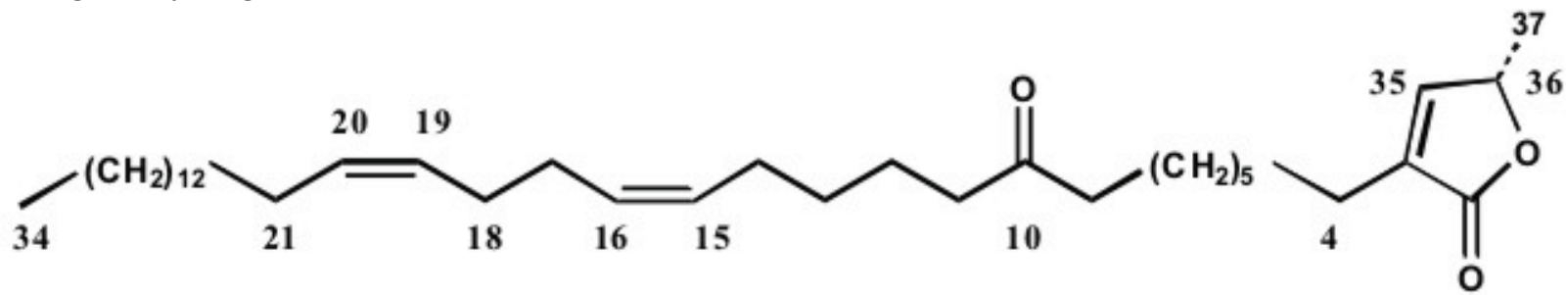

\section{MATERIAL AND METHODS}

\section{Instrumentation}

Melting points were determined on a Mel-Temp apparatus and are uncorrected. IR spectra (film) were recorded on a Perkin-Elmer 1420 spectrometer. UV spectra were taken on a Beckman DU-7 ${ }^{1} \mathrm{H}-\mathrm{NMR}$ and ${ }^{13} \mathrm{C}-\mathrm{NMR}$ spectra were recorded in $\mathrm{CDCl}_{3}$ solutions in a Bruker AV$400 \mathrm{MHz} / 125 \mathrm{MHz}$. The mass spectra were taken at $70 \mathrm{eV}$ (probe) in a Shimadzu QP-2000, and on Kratos MS50. Silica Gel (200-300 mesh) was used for column chromatography (CC) and silica HF-254 for TLC. Spots were detected on TLC by heating after spraying with $5 \%$ phosphomolybdic acid in EtOH. Absorbances for protein determination were measured on a Beckman DU-7 spectrophotometer. Oxygen consumption was measure using a YSI Model 5300 biological oxygen monitor with Clark-type electrode [YSI Incorporation, 1986]. Mitochondrial inhibition assays were performed at $30^{\circ} \mathrm{C}$. Centrifugation were performed on a Sorvall Superspeed RC2-B at $4{ }^{\circ} \mathrm{C}$.

\section{Plant material}

Twigs of Xylopia emarginata Mart. (Annonaceae) were collected in Cuao river, in state Amazonas of Venezuela (April 1998), and were identified by Professor Anibal Castillo, School of Biology, Universidad Central de Venezuela, where a voucher specimen (AC-5497) was deposited in the herbarium of Botanical Garden of Caracas.

\section{Bioassay materials}

Trizmabase(Tris[hydoxymethyl]aminomethane), DL-malic acid, L-glutamic acid (monopotassium salt), adenosine 5-diphosphate (potassium salt; from yeast ATP), rotenone, EDTA, sucrose, potassium chloride, potassium phosphate (potassium dihydrogen phosphate), monobasic, dye, and bovine serum albumin (BSA), were purchased from commercial sources. The isolation buffer consisted for $4 \mathrm{mM}$ tris- $\mathrm{HCl}, 0.5 \mathrm{mM}$ EDTA, and $250 \mathrm{mM}$ sucrose at a $\mathrm{pH}$ of 7.4. It was kept on ice at all times. The assay buffer consisted of $100 \mathrm{mM} \mathrm{KCl}, 5 \mathrm{mM} \mathrm{KH} \mathrm{PO}_{4}, 1 \mathrm{mM}$ EDTA,

\section{Product, extraction and isolation}

The pulverized twigs $(0.8 \mathrm{~kg})$ were extracted with chloroform in a Soxhlet for $24 \mathrm{~h}$. The extract was concentrated under reduced pressure yielding $80 \mathrm{~g}$ of crude chloroform extract (FOO1). The dry FOO1 was partitioned, with $\mathrm{CH}_{2} \mathrm{Cl}_{2}: \mathrm{H}_{2} \mathrm{O}(1: 1)$, to obtain the bioactive (BST $\mathrm{LC}_{50} 194 \mathrm{ppm}$ ) (Meyer et al., 1982) residue FOO2 (8 g). FOO2 was subjected to column chromatography on silica gel $(0.5 \mathrm{~kg})$ and fractionated into twenty fractions with a gradient of hexane-EtOAc-MeOH. The active fraction $\mathrm{P} 2$ $\left(\mathrm{F}_{1-4}-\mathrm{F}_{1-8}\right)\left(1 \mathrm{~g}, \mathrm{BST} \mathrm{LC}_{50} 127 \mathrm{ppm}\right)$ (Meyer et al., 1982) was further resolved on reverse phase column eluted with $\mathrm{MeOH}: \mathrm{H}_{2} \mathrm{O}$ (gradient) to afford compound Xymarginatin 1. The structure of the compound $\mathbf{1}$ was established by ${ }^{1} \mathrm{H}-$ RMN, ${ }^{13} \mathrm{C}-\mathrm{RMN}, \mathrm{COSY}, \mathrm{HMBC}, \mathrm{HMQC}$ and MS.

Xymarginatin (1): White waxy solid (17 mg); mp: $69-70^{\circ} \mathrm{C}$; UV. $\left.\lambda_{\text {max }}, \mathrm{MeOH}, \mathrm{nm}\right): 218.6, \log \varepsilon$ 3.30; IR (film) cm $\mathrm{cm}^{-1}: 3360,2941,2897,1750,1705,1648,1452$, 1282. CIMS (isobutene) $m / z[\mathrm{MH}]^{+} 557$ (20\%), EIMS m/z $\mathrm{M}+556(11 \%)$ and fragmentation (Figure 1); ${ }^{1} \mathrm{H}-\mathrm{NMR}$ $\left(\mathrm{CDCl}_{3}, 400 \mathrm{MHz} \delta\right.$ ppm). $6.94(1 \mathrm{H}, \mathrm{q}, J=7.0 \mathrm{~Hz}, \mathrm{H}-9)$; $5.32(4 \mathrm{H}, \mathrm{ddd}, J=11.0 \mathrm{~Hz}, J=6.9 \mathrm{~Hz}, J=6.4 \mathrm{~Hz}, \mathrm{H}-15$, H-16, H-19, H-20); 4.96 (1H, q, $J=7.0$ Hz, H-36); 2.33 (2H, m, H-9); 2.34 (4H, m, H-11 ); 2.31 (2H, m, H-3 ); 2.03 (4H, dd, H-15, H-21 ); 1.98 (4H, dd, H-17, H-18 ); 1,54 (2H, m, H-4); 1.41 (3H, d, $J=6.99$ Hz, H-37); 1.22$1.74(2 \mathrm{H}, \mathrm{m}, \mathrm{H}-23$ and $\mathrm{H}-30) ; 0.86(3 \mathrm{H}, \mathrm{t}, J=7.0 \mathrm{~Hz}$, H-36).

${ }^{13} \mathrm{C}-\mathrm{NMR}\left(\mathrm{CDCl}_{3} ; 125 \mathrm{MHz}, \delta \mathrm{ppm}\right): 211.4$ (C-10), 173.9 (C-1), 149.0 (C-35), 134.2 (C-2), 130.4 (C-19), 130.18 (C-15), 129.14 (C-18), 129.07 (C-14), 77.59 (C-36), 42.87 (C-9), 42.75 (C-11), 31.9 (C-3), 27.46 (C-16), 27.37 (C-17), 27.31 (C-20), 23.89 (C-13), 22.7 (C-33), 19.1 (C-37), 14.1 (C-34).

\section{Mirochondrial isolation}

The procedures used in these experiments were reviewed and approved by the Animal Care and Use Committee of the School of Pharmacy, Universidad Central de Venezuela.

Animals: Male Sprague-Dawley rats (300-320 g). Each animal was sacrificed with carbon dioxide. The 
method for isolating rat liver mitochondria essentially followed the published methodology (Landolt et al., 1995; Alfonso et al., 1996). The mitochondrial pellet was reserved and resuspended in $1 \mathrm{~mL}$ of assay buffer and immediately used for oxygen consumption. The protein concentration of the mitochondrial sample was determined using the Bradford assay (Bradford, 1976). Bovine serum albumin was used as the standard. In the sample chamber, protein concentration typically ranged from 1.0 to $1.8 \mathrm{mg} /$ $\mathrm{mL}$.

\section{Mitochondrial inhibition assay}

The mitochondrial assay was initiated by allowing $2.9 \mathrm{~mL}$ of assay buffer to equilibrate $\left(30^{\circ} \mathrm{C}\right)$ for $5 \mathrm{~min}$, in the sample chamber. $0.1 \mathrm{~mL}$ of the mitochondrial suspension was then added, the mixture was equilibrated for $1 \mathrm{~min}$, and the electrode was inserted. After stabilization of the initial State 4 respiration, $5 \mu$ of a $0.05 \mathrm{M}$ aqueous ADP solution was added, and State 3 (transformation of ADP into ATP) and State 4 respiration were allowed to stabilize (about $3 \mathrm{~min}$ ). Next, $10 \mu \mathrm{L}$ of the freshly prepared acetogenin 1 solution (in $95 \%$ ethanol) was added followed by ADP ( 5 $\mu \mathrm{L}$ ) after $2 \mathrm{~min}$. Again State 3 and State 4 respiration occur. Six different concentrations were used, and at least three measurements were performed for each concentration. The concentrations used were $1.5 \times 10^{-4} 2.5 \times 10^{-4} \mathrm{M} ; 3$ x $10^{-4} \mathrm{M} ; 5 \times 10^{-4} ; 6 \times 10^{-4} ; 7.5 \times 10^{-4} \mathrm{M}$ and $10 \times 10^{-4} \mathrm{M}$. The slopes of State 3 and State 4 were calculated without inhibitor (S1 and S2) (RCR) and the in the presence of the inhibitor (S3 and S4). The percentage of inhibition for each determination was calculated using the following equation: percentage of inhibition at concentration $\mathrm{C}=$ 100-[(S3-S4/S1-S2) x 100] (Alfonso et al., 1996).

The concentration of $\mathbf{1}$ in the sample chamber (nM) were divided by the concentration of proteins in the sample chamber $(\mathrm{mg} / \mathrm{mL})$, resulting in inhibitory concentrations expressed in $\mathrm{nM} / \mathrm{mg}$ protein. In order to determine the values and the confidence intervals, linear regression with percentage of inhibition as the response variable and the the concentration $\mathrm{C}$ as the explanatory variable were run, from the fitted models we estimated $\mathrm{IC}_{50}$. To determine normal $95 \%$ confidence intervals, we use the probit program. Rotenone was included as a positive control and is a well known inhibitor of the NADHubiquinone oxidoreductase coupling site (Complex I).

\section{RESULTS AND DISCUSSION}

Xymarginatin (1) was isolated as a waxy solid. The CIMS of 1 gave a $\mathrm{MH}^{+}$at 557, and EIMS an $\mathrm{M}^{+} 556$. The molecular formula was established to be $\mathrm{C}_{37} \mathrm{H}_{64} \mathrm{O}_{3}$ on the basis of EIMS, CIMS and NMR. Analyses of the EIMS fragmentation of compound $\mathbf{1}$ demonstrated that the carbonyl group was located at C-10 as shown in Figure 1.

The lack of absorption at $3360 \mathrm{~cm}^{-1}$ in IR indicated no presence of $\mathrm{OH}$ groups in compound 1. As with other acetogenins (Zeng et al., 1996), the presence of a methyl substituted $\alpha, \beta$-unsaturated $\gamma$-lactone without 4-OH group was suggested by the IR $\left(\mathrm{V}_{\max } 1750 \mathrm{~cm}^{-1}\right), \mathrm{UV}$ $(\lambda \max 218.6 \mathrm{~nm})$, and the corresponding resonances $(\delta$; ppm) in the ${ }^{1} \mathrm{H}$ and ${ }^{13} \mathrm{C}-\mathrm{NMR}$ spectra: ${ }^{1} \mathrm{H}-\mathrm{RMN}$ at $\delta 6.96$ ppm, q (H-35), 4.96 ppm, dq (H-36), 1.41 ppm (H-37), $2.31 \mathrm{ppm}, \mathrm{m}(\mathrm{H}-3)$, and carbons resonances at $173.9 \mathrm{ppm}$ (C-1), 149.0 ppm (C-35), 134.2 ppm (C-2), 77.5 ppm (C-36) and $19.1 \mathrm{ppm}$ (C-37). Four olefinic protons, were discerned in the ${ }^{1} \mathrm{H}-\mathrm{NMR}$ spectrum at $5.34 \mathrm{ppm}(4 \mathrm{H}$, ddd, $J=11.0 ; 6.8 ; 6.4 \mathrm{~Hz}$ ), suggesting the presence of two isolated cis-double bond; this group was further confirmed by four methinic carbon resonances at $130.4 \mathrm{ppm}, 130.1$ ppm, $129.2 \mathrm{ppm}$ and $129.0 \mathrm{ppm}$ (experimental section). The positions of the double bonds were determined by the EIMS fragmentation (Figure 1) and from the COSY and $\mathrm{HMBC}$ spectra (Figure 2), to be at C-15 and C-16 and $\mathrm{C}-18$ and $\mathrm{C}-19$. Examination of the ${ }^{1} \mathrm{H}-{ }^{1} \mathrm{H}$ COSY spectrum revealed that the doubles bonds moieties are separated by two methylene units. The presence of an additional carbonyl signal at $1705 \mathrm{~cm}^{-1}$ in the IR spectrum suggested that compound $\mathbf{1}$ is a keto-acetogenin compound. The ${ }^{1} \mathrm{H}-$ NMR data also suggested the location of the keto group at $\mathrm{C}-10$ since two additional two-proton triplets $(J=7.5$ $\mathrm{Hz}$ ) are shown in the spectrum of 1 , at $\delta 2.34 \mathrm{ppm}$ and 2.33 ppm, consistent with two methylene groups at C-9 and C-11, flanking the keto group. The location of the keto group was then clearly confirmed at $\mathrm{C}-10$ on the basis of EIMS fragmentation (Figure 1).

\section{Biological activity}

We determined the concentration of acetogenin that decreased the RCR to $50 \%$ of the control RCR value $\left(\mathrm{IC}_{50}\right)$. Table 1 illustrates the effects of the xymarginatin on mitochondrial respiration and show mitochondrial respiratory results as a percentage of the control respiration (RCR, 100\%). The $\mathrm{IC}_{50}$ determined for xymarginatin was $1720 \mathrm{nM}$. We also demonstrated the effects, in the mitochondrial respiratory system of rotenone $\left(\mathrm{IC}_{50} 34.5\right.$ $\mathrm{nM}$ ) a classical mitochondrial inhibitor at Complex I.

Table 1. Bioactivities of xymarginatin $\mathbf{1}$ and rotenone.

\begin{tabular}{|c|c|c|}
\hline Compound & $\begin{array}{l}\text { Rat mitochondrial bioassay } \\
\qquad \mathrm{IC}_{50}(\mathrm{nM})\end{array}$ & $\begin{array}{c}\mathrm{BST}^{\mathrm{b}} \\
\left.\mathrm{LC}_{50} \mu \mathrm{g} / \mathrm{mL}\right) \\
\end{array}$ \\
\hline Xymarginatin (1) & 1720 & $\begin{array}{c}127 \\
(80.9 / 175.7)\end{array}$ \\
\hline Rotenone & 34.8 & 1.8 \\
\hline \multicolumn{3}{|c|}{ apositive mitochondrial inhitor control. ${ }^{\mathrm{b}}$ Brine shrimp assay. } \\
\hline & & $\begin{array}{l}\text { Bras. Farmacogn. } \\
\text { z. J. Pharmacogn. } \\
\text { ): Out./Dez. } 2009\end{array}$ \\
\hline
\end{tabular}




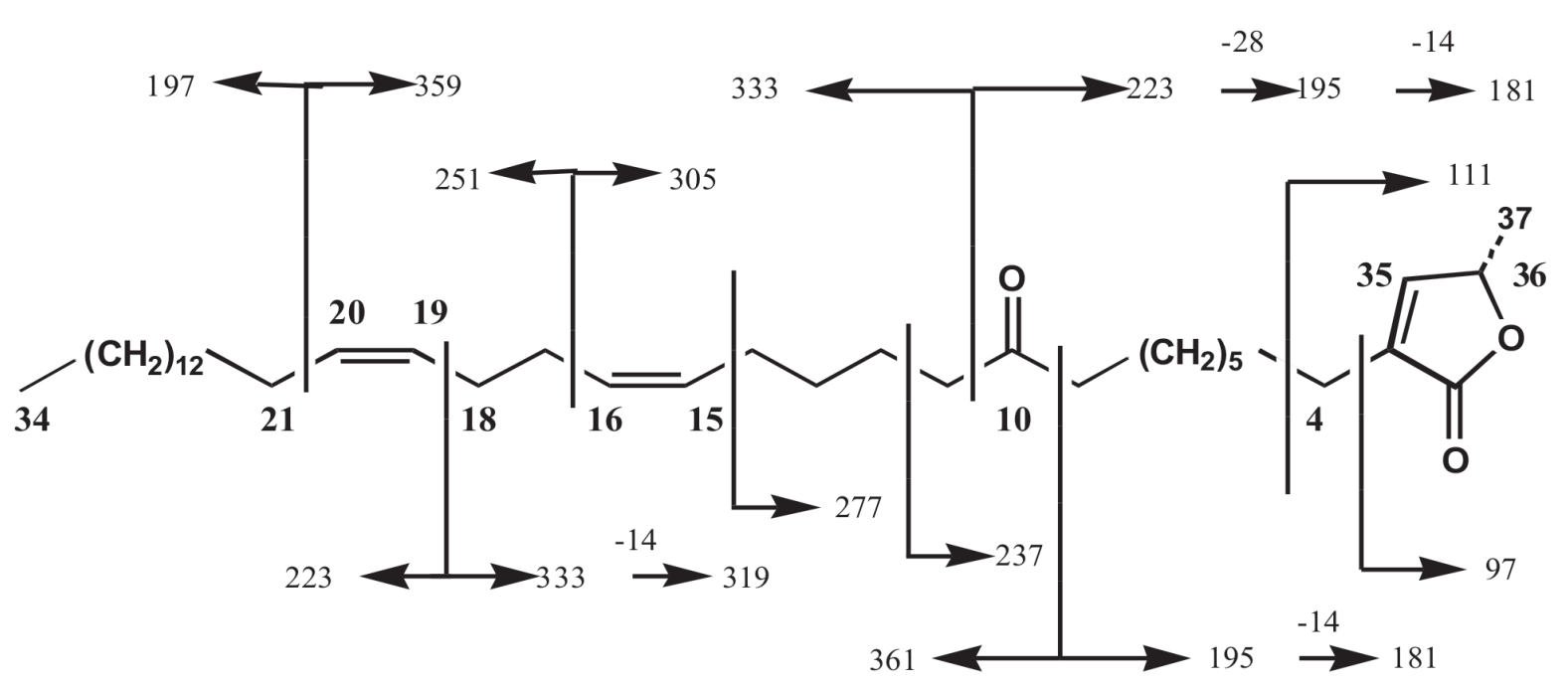

Figure 1. Diagnostic eims fragmentation ions of xymarginatin (1).

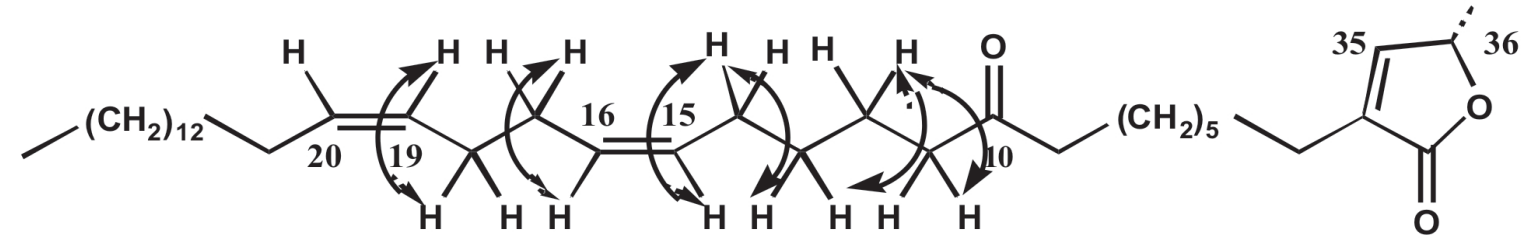

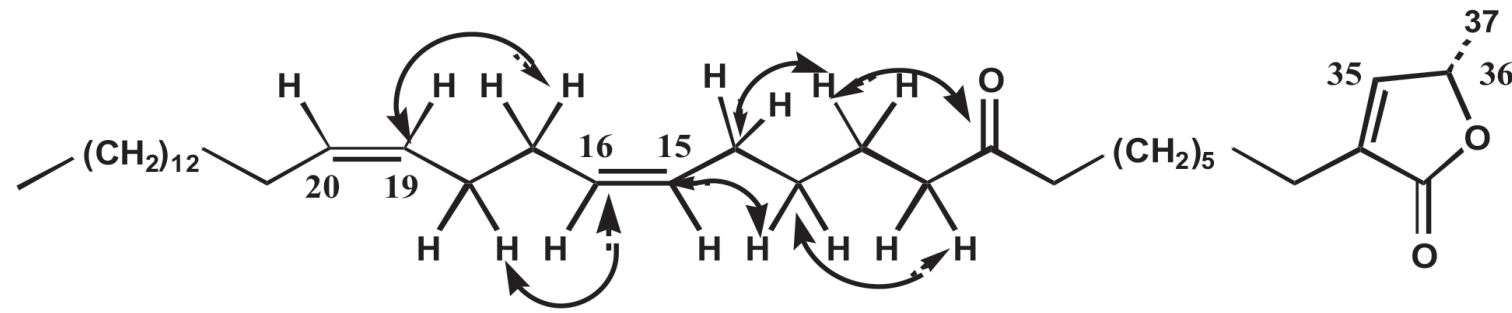

B

Figure 3. A. ${ }^{1} \mathrm{H}-{ }^{1} \mathrm{H}$ correlations in the COSY -NMR spectrum of xymarginatin; $\mathrm{B} .{ }^{1} \mathrm{H}-{ }^{13} \mathrm{C}$ correlations in the HMBC-NMR spectrum of xymarginatin.

\section{CONCLUSION}

A new linear Annonaceous acetogenin, xymarginatin (1) was isolated from the twigs of Xylopia emarginata Mart. (Annonaceae). The $\mathrm{IC}_{50}$ value (1720 $\mathrm{mM}$ ) for inhibiting oxygen consumption suggested that xymarginatin (1) have moderate potency as inhibitor of mitochondrial electron transfer.

\section{ACKNOWLEDGMENTS}

This investigation was supported, in part, by
CDCH 06.00.6994-2007. CYTED-XP RIDEST for EIMS and CIMS.

\section{REFERENCES}

Alfonso D, Johnson H, Colman-Saizarbitoria T, Presley C, McCabe G, McLaughling J 1996. SARs annonaceous acetogenins in rat liver mitochondria. Nat Toxins 4: 18188.

Bermejo A, Figadere B, Zafra-Polo MC, Barrachina I, Estornell E, Cortes D 2005. Acetogenins from annonaceous: recent progress in isolation, synthesis and mechanisms of action. Nat Prod Rep 22: 269-303.

Bradford M 1976. Arapid and sensitive method for quantitation of microgram quantities of protein utilizing the proteindye-binding. Anal Biochem 72: 248-54. 
Colman-Saizarbitoria T, Johnson H, Alali FQ, Hopp DC, Roberts LL, McLaughlin J 1998. Annojahnin from Annona jahnii: a possible precursor of mono-tetrahydrofuran acetogenins. Phytochemistry 49: 1609-1616.

Colman-Saizarbitoria T, Amesty A, Amaro MI, Cordero M, Bahsas A 2008. Jahonin and asimicin acetogenins from Annona jahnii (Annonaceae). Rev Fac Farm 71: 47-52.

Chih-Chuang L, Fang-Rong Ch, Shu-Li Ch, Chin-Chung W, Kuo-Hsiung L, Yang-Chang W 2005. Novel cytotoxic monotetrahydrofuranic annonaceous acetogenins from Annona montana. Bioorgan Med Chem 13: 4767-4776.

Fall D, Gleve C, Franck X, Laurens A, Hocquemiller R 2002. Cis-bullatencin, a linear acetogenin from roots of Uvaria chamae. Nat Prod Lett 16: 315-321.

Landolt JL, Ahammadashib KI, Hollingworth RM, Barr R, Crane FL, Buerck NL, McCabe GP, McLaughlin JL 1995. Chem Biol Interact 20: 1-13.

Meyer BN, Ferrigni NR, Putnam JE, Jacobsen LB, Nichols DE, McLaughlin JL 1982. Brine shrimp: convenient general bioassay for active constituens. Planta Med 45: 31-34.

Mesquita ML, Grelier P, Mambu L, De Paula JE, Espinola LS 2007. In vitro antiplasmodial activity of brazilian cerrado plants used as traditional remedies. J Ethnopharmacol 110: $165-170$.

Moreira I, Henriquez J, Lago G, Roque N 2003. Alkaloids, Flavonoids and Terpenoids from leaves and fruits of Xylopia emarginata (Annonaceae). Biochem Syst Ecol 31: 535-537.

Moreira I, Henriquez J, Roque L, Contini K, Henrique J, Lago G 2007. Sesquiterpenos e hidrocarbonetos dos frutos de Xylopia emarginata (Annonaceae). Rev Bras Farmacogn 17: 55-58.

Morré DJ, de Cabo R, Farley C, Oberlies NH, McLaughlin JL 1995. Mode of action of bullatacin, a potent antitumor acetogenin: inhibition of NADH oxidase activity of HeLa and HL-60, but not liver, plasma membranes. Life Sci 56: 343-348.

Oberlies NH, Croy VL, Harrison ML, McLaughlin JL 1997. The Annonaceous acetogenin bullatacin is cytotoxic against multidrug-resistant human mammary adenocarcinoma cells. Cancer Lett 115: 73-79.

Saúde-Guimaráes D, Faria A 2007, Substancias da naturaleza com atividade anti-Trypanosoma cruzi. Rev Bras Farmacogn 17: 455-465.

Tormo J, Estornell E, Gallardo T, González MC, Cavé A, Granell S, Cortes D, Zafra-Polo MC 2001. $\gamma$-Lactonefunctionalized antitumoral acetogenins are the most potent inhibitors of Mitochondrial Complex I. Bioorg Med Chem Lett 11: 681-684.

Zeng L, Ye Q, Oberlies NH, Shi G, Gu Z-M, He K, McLaughlin J 1996. Recent advances in annonaceous acetogenins. Nat Prod Rep 13: 275-280. 